\title{
The other way round: manufacturing as an extension of services in small island states
}

\section{Godfrey Baldacchino}

\begin{abstract}
Try valiantly though they might, small (often island) territories cannot possibly follow the hard-and-fast logic of industrialisation marked out for them by larger economies. Instead, they have worked out for themselves an alternative resort to manufacturing industry; they have done so on the basis of a pragmatism in part derived from the handicaps imposed by the architecture of global capitalism and colonialism. This 'hands on' approach involves: (1) the exploitation of the rentier status of a microstate as a base or platform for 'merchandise'; (2) the provision of goods (apart from services) for privileged export purposes, particularly aimed at captured markets (such as tourists and small state diasporas); (3) the expansion into small, knowledge-based industries; and (4) the parallel preservation of part-time small scale, cottage industry, often in relation to self employment. In all four cases, the common denominator and main argument proposed is that manufacturing in micro-states is best seen as an extension of services, rather than the other way round as is generally proposed.
\end{abstract}

Keywords: small states, industrialisation, manufacturing, services, knowledge-based industries, rentier status, microstates

It appears to be the awesome destiny of a global village to be prone to the adoption of one, domineering, all inclusive, paradigm of being and becoming after another. Yet, small island states and territories ${ }^{1}$ appear to have no option but to fall unceremoniously out of the embrace of these grand and lofty "oneworldist' explanations, biased as these have been in favour of the big and continental.

This paper will argue that, try valiantly though they might, small island territories cannot possibly follow the paradigmatic logic of industrialisation marked out for them by larger economies. Instead, they have pragmatically worked out for themselves an alternative resort to manufacturing industry, a pragmatism in part derived from the handicaps imposed by the architecture of 
global capitalism and colonialism. This 'hands on' approach goes against the grain of mainstream economic theory but it nevertheless makes ample sense to, and in, the micro-insular domain.

\section{THE ARGUMENT}

An inductive analysis of current micro-insular practice reveals four general viable approaches to the question of manufacturing production. These are: (1) the exploitation of the rentier status of an island as a base or platform for 'merchandise'; (2) the provision of goods (apart from services) for privileged export purposes, particularly aimed at captured markets (such as tourists and small island diasporas); (3) the expansion into small, knowledge-based industries; and (4) the parallel preservation of part-time small scale, cottage industry, often in relation to self employment.

In all four cases, the common denominator and main argument proposed is that manufacturing in small island states is best seen as an extension of services, rather than the other way round and as is generally proposed. With high access and transport costs in and out of the island territory, a typically well paid workforce, the absence of locally available inputs and the distance and fragmentation of markets - a manufacturing strategy based on high volume commodity production for export - by local as much as by invited foreign investment - is likely to flounder. Perhaps such reasoning only makes sense as a short to medium term strategy.

Yet, there are plausible alternatives to this approach. Furthermore, these options are based on the inherent strengths and competitive advantages of the small, often isolated, island site. Rather than promoting the advantages of other, non-microstate players, such alternatives capitalise on the microterritory's natural disposition as the perennial service economy. The smaller the territory, the stronger the argument, and this is all the more so when there is an absence of exploitable natural resources, on land or in the sea.

\section{The siren song of development}

Until a decade or so ago, the principle benchmark of economic performance was still dictated by notions of 'development': a supposedly linear, purposeful and directed transition towards a modern, urban-based, market-oriented, private-sector led society which enjoys the quality of life of comparable, model societies in the metropole (Hettne, 1990: 80; Preston, 1982). The startling economic growth of role-models, the availability of finance capital looking for greenfield sites, the competitive cold war context and the rapid wave of decolonisation ... such a combination of factors contributed to a clientele of newly independent nation states anxious to emulate the economic miracle of their erstwhile colonial masters and therefore to reap its benefits.

Within this project, industrialisation was meant to play a pivotal and catalytic role. It was the obvious magnet to attract 'unproductive labour' away from stagnant agriculture or underproductive rural endeavours. It was the 
intended provider of mass employment for men and women in urban surroundings. It would be the site of generous, locally derived value added, reducing the drain of foreign currency in the purchase of costly imports. It would serve as a cradle for the development of new skills, disciplines, aptitudes and technologies, both upstream and downstream in the product cycle. It would also itself create a demand for many services which, in turn, would create many more local, non-seasonal, full-time jobs. It was a clear recipe for success and the industrial world - whether of the private or of the state capitalist variant was there to prove it (Seers, 1982: 74).

The industrialisation path was not only desirable; it was also allegedly unavoidable. There were - there could be - no shortcuts to progress (Hyden, 1983). The strategy was couched within an aura of inevitability, a stage within the natural evolution of economic systems. Different economies may have arrived at their appointment with industrialisation at different times; so much was an accident of history, of colonial policy, of fledgling capitalism, of administrative inertia. But the appointment had to be kept if some kind of 'take-off' into economic growth was expected (Rostow, 1956). Such an evolutionary economic model was juxtaposed by a just as firmly rooted, imperial notion of a 'natural' progression from colonial to sovereign independent status (Bertram, 1988: 17).

It appears fortuitous in hindsight that many small island developing states did not follow the industrialisation route so fervently. Not because of some suspicion as to its intended benefits; they remain just as, if not even more, enthralled with the irresistible and taunting potential of industrial power and its spinoffs. But industrialisation simply could not happen because the critical variables had either been surgically removed or had been missing all along. (Data on the relative and limited importance of manufacturing to small developing economies is provided in Table 1.)

To extend the 'take off' analogy popularised by Rostow, many microstates, like frogs, simply cannot fly; try though they might, they could only muster and deploy an amazing capacity to jump and avoid the snake of economic ruin just as, if not more effectively than, their flying associates did (Katzenstein, 1985). Where other developing countries aimed at the long term goal of selfreliance and economic independence, microstates went for 'dependent development' and a better integration into the world system (Hoetjes, 1992: 142-3; Sutton, 1987: 20-1). Where others sought to maximise productive capacity, microstates attempted to maximise consumptive capacity (Baldacchino, 1993: 39). Where others struggled for decolonisation and political independence, many small territories have been champions at forestalling independence and so many still today cling tenaciously to their colonial status (Crusol, 1980; Hoefte \& Oostindie, 1991: 93; Winchester, 1985). Where others found themselves subject to a drain of resources - human, financial, material - to the core, microstates opted instead to maintain and cultivate the economics of productive diplomacy which turned unequal exchange topsy turvy and assured a transfer from the core to the insular periphery (Brookfield, 1987: 56-7; Taylor, 1987: 1-3). Whereas others sought 
Table 1. Manufacturing industry in small island states

\begin{tabular}{lcccc}
\hline & \multicolumn{2}{c}{ As \% of GDP } & \multicolumn{2}{c}{ As \% of Labour Force } \\
Country & 1980 & 1995 & 1980 & 1994 \\
\hline Antigua \& Barbuda & 20 & 19 & 20 & 20 \\
Bahamas & 30 & 14 & 15 & 10 \\
Barbados & 22 & 16 & 21 & 13 \\
Cape Verde & 17 & 14 & 23 & 22 \\
Comoros & 13 & 13 & 6 & 3 \\
Cyprus & 34 & 25 & 34 & 22 \\
Dominica & 21 & 22 & 16 & 13 \\
Fiji & 22 & 18 & 17 & 12 \\
Grenada & 13 & 19 & 10 & 14 \\
Kiribati & 9 & 9 & 4 & 4 \\
Maldives & 6 & 17 & 22 & 22 \\
Malta & 42 & 35 & 41 & 25 \\
Mauritius & 26 & 32 & 24 & 41 \\
St Kitts \& Nevis & 27 & 25 & 22 & 20 \\
St Lucia & 25 & 15 & 7 & 9 \\
St Vincent \& the Grenadines & 27 & 19 & 17 & 15 \\
Sao Tome \& Principe & 15 & 26 & 13 & 20 \\
Seychelles & 16 & 15 & 23 & 21 \\
Solomon Islands & 4 & 3 & 10 & 8 \\
Tonga & 8 & 19 & 5 & 11 \\
Vanuatu & 16 & 14 & 7 & 8 \\
Western Samoa & 12 & 20 & 8 & 8 \\
\hline
\end{tabular}

Source: Commonwealth Secretariat (1996, Tables 3 \& 26; 1997, Table 4.1).

to move from subsidy to subsistence, microstates have shown a clear preference to 'kill the economy through kindness' (Hintjens 1991: 51), to move from subsistence to subsidy (Connell, 1992; McKee \& Tisdell, 1990: 170) or, better still, a strategic combination of these two at different levels of the local economy.

\section{Import substituting or export led industrialisation?}

The establishment of import-substituting industries has proved difficult for small island territories because of the constraining effects of small size, market fragmentation, limited labour supply and skills, high costs from energy and raw material inputs, few local inter-industry linkages, inadequate access to technology and investment capital, and massive political pressures to maintain inefficient industries in operation as heavily subsidised or protected white elephants (Connell, 1991; McKee \& Tisdell, 1990: 18; Ramsaran, 1989: 1,139; Selwyn, 1975). The establishment of export-oriented manufacturing production was even more difficult, compounded further by precarious environmental conditions, fluctuating commodity prices, inadequate access to markets as well as high labour and transport costs (Demas, 1965; Dommen \& Hein, 1985; Jalan, 1982). Partial success has 
been achieved in a very limited number of areas, such as fish processing and mineral production. Otherwise, export products have been restricted (or should one say channelled by colonial policies?) towards primary products mainly cash crops such as sugar, copra, bananas, tea and cocoa - introduced on a plantation system to finance colonial administrations. These suffer deteriorating terms of trade beyond local control. Even some of the major industries have survived by virtue of state intervention, which includes subsidies and tax concessions (Fairbairn, 1988a: 58).

Some success has been admittedly achieved in terms of that seductive option: export oriented industrialisation by invitation (McKee \& Tisdell, 1990: $14,153)$. But the price to be paid is heavy and the benefits gained may be largely illusory. With few exceptions, there would be virtually no significant 'screwdriver' export industries without heavy subsidies and positively discriminatory legislation (Waugh, 1987). Tax concessions, accelerated depreciation, the facility to repatriate profits, dividends and capital, training grants for employees and new recruits, low wages, restricted or outlawed trade union organisation, cheap land, even cheap power, to set up operations (Bacchus, 1989: 10; Barry et al., 1984: 64-5). The main beneficiary is also likely to be footloose capital which does not generate the sustained, export growth orientation so many microstate governments desire (Faber, 1992: 1334; Taylor, 1984: 34). In such circumstances, any quest for international competitiveness by manufacturing firms based in small islands requires that the real wage be forced down and/or that preferential access is secured, thus compensating for the other non-competitive transaction costs (Bertram, 1988: 28). Meanwhile, Fiji, Malta and Mauritius - the only three small island developing states to graduate clearly as sites of export manufactures - may have done so thanks to the transient comparative advantage of relatively cheap labour and equally transient concessionary access to niche export markets. The latter may not last long in the more openly competitive, liberal and multilateralist post-GATT trade regime (Armstrong \& Read, 1998; Commonwealth Secretariat, 1997: Chapter 6).

Being open economies with a 'dependency receptor orientation', small island territories have been bred to expect and accept a whole range of imports from the metropole - ranging from the obvious (goods and services) to the less obvious (consultancy services, legal systems, tourist flows, educational systems, bilateral and multilateral aid, foreign direct investment, consumer tastes ...) (Khan, 1976: 49). A 'what is foreign is best' syndrome ensured that alien imports enjoy high status in such 'creolised' societies (Will, 1981: 135) and can thus compete well even with local variants which sell at a lower price.

\section{STRANGE RECIPES OF AN EQUALLY STRANGE SUCCESS}

In contrast, we find that small island bases have succeeded best in the following four general areas of 'production': 


\section{Rent recipients}

Firstly, so many microstates today survive by thriving on a 'rentier status' in the world economy (Bertram, 1993; Kaplinsky, 1983: 203-4; Payne, 1991: 18). Rents are revenues which are divorced from any directly productive activity on the part of the recipient (Bertram \& Watters, 1985: 500). They constitute income which depends on the economic activities of rent generating countries elsewhere (Kakazu, 1988: 5). These revenues include aid, dividends from foreign securities, stamp duties, customs receipts, land or fishing taxes, leases, loans and payments for the provision of various services - tourism, banking, tax havens, finance, military bases, casinos, yacht berths, space tracking facilities, trans-shipment, flags of convenience, bunkering, waste dumping sites, philately and other collectors' items - what are collectively known as 'invisible receipts' (Crocombe, 1987; Legarda, 1984: 43). One of the latest such 'commodities' is electronic mail addresses. The specific object securing rent receipts may and does change with time - such as with declining geostrategic and increasing environmental value - but, fundamentally, the rentier orientation itself does not.

Such activities tend to carry a sense of aversion : is this a resilient carry-over from David Ricardo's dismissal of rentiers and Karl Marx's predilection for productive labour (Chattopadhyay, 1987: 48)? Yet, it is such trade rather than manufacturing which characterises the main, market based economic thrust of many small islanders. It is the commercial, mercantile elite which occupies the pinnacle of the local, socio-economic class structure (Barrow \& Greene, 1979: Chapter 2).

Perhaps it would make sense to consider the location of foreign manufacturing capacity in micro-territorial bases (and not just military or administrative capability) as itself an aspect of 'rent'. The provision of free factory space, tax holidays, free repatriation of profits and dividends, etc. in a particular location constitute a 'geo-strategic service' to the would-be manufacturers and this package, location included, is what entices the investor to come over. After all, that is what small islands can generally offer; and 'geo-strategic rent' in the guise of wages is generally what they get in return (Poirine, 1995). There is hardly any other spill-over into the domestic economy.

\section{Marketing locality}

A second area of particular importance to small island territories concerns the provision of goods (apart from services) to captured, 'privileged' markets. I understand these privileged, captured markets to comprise specific niche centres of consumption which have a disposition to purchase goods from the island site, not because of the inherent quality or price competitiveness of the goods/services but because these come specifically from that particular location. Through such a 'marketing of identity' (Fairbairn, 1988a: 75), the structural disadvantage of the added cost of production, non-economies of scale, transport and freight is somehow rendered superfluous. 
There are two main types of such 'privileged export' niches: one is the transitory tourist market. Island tourists are typically richer than average consumers, having managed to make it to remote and generally more expensive destinations. Once there, they may be brought to savour a more authentic island experience by appreciating and adopting local consumer habits. Of course, such tourists are most likely to result from, and conform to, a specific tourism marketing policy which advocates insular uniqueness and appeals mostly to the drifter and geocentric oriented tourist types (Cohen, 1972 \& Perlmutter, 1969 respectively). This is in contrast to just another paradise fully constructed and draped in the garb of the tourist's own country of origin - furniture, recreation, food, housing, transport ... (Wilkinson, 1989: 168; Robertson, 1992: 174). Such a stance would also reduce the substantial flow of foreign currency resorted to in recreating the tourist's total home ambience. The very geography of islands fosters an innate opportunity towards such a branding of the insular tourism product which thus also remains firmly under local control.

The second aspect of 'privileged export' concerns the diaspora of islanders and their families living abroad. Emigrants are already part of the unproductive, exotic and unlikely exportable commodities of small islands along with seashells and stamps. They constitute a deliberate loan of human capital, a critical component of the 'trans-national corporation of kin' (Bertram \& Watters, 1985: 499) which symbiotically contributes useful remittances to families left stranded at home. They may be tapped further both as a lucrative market for exported 'genuine island products' and as the transposed sites for productive island-led investment. Indeed, what may prove uneconomical in the small state may prove worthwhile in, or for, Auckland, Sydney, San Francisco, Miami, Toronto, London, Paris, Vancouver and Amsterdam: there, the number of immigrant islanders may even exceed the number left at home and where per capita purchasing power is typically much higher (Lowenthal, 1987: 41-3; Watters, 1988: 36-8). This constitutes the microstate's best response yet to an 'export or perish' condition - an internationalisation of relatives colonising niches of economic opportunity (Bertram, 1988: 28). By the way, emigrants also comprise a steady quantity of more eco-friendly, long stay tourists and frequent visitors to their island site of origin.

\section{Knowledge based services}

The third, profitable area of 'productive investment' consists in the cultivation of small, knowledge based - rather than resource based - industries. Knowledge has been long pronounced to be the lynch pin of the postindustrial age. Who better placed to exploit this development than small territories, since they have inadvertently missed the industrialisation phase and have found themselves strategically poised where they have been all along, in a post-industrial, service-dominated scenario?

The trouble with manufacturing is that it has been dominated all along by physically, tangible products - whether as inputs (such as raw materials and power), throughputs (such as machines and process technologies) or outputs 
(commodities). Their dependence on expertise, their weight, volume, high unit costs of production and perishable nature bestow an insurmountable handicap to those small islands bent on procuring, producing and exporting them at a profit. If resources suddenly assume the nature of intangibles - such as information and communication services - than such ingrained handicaps could very well disappear.

On this front, entrepreneurs from small remote locations may confidently compete on the world stage. With the right infrastructural provisions (including internet capability; fibre optic telephone systems: world wide satellite telecommunications networks) and a supportive educational system which fosters knowledge, training and enterprise in such a growing economic sector, useful and lucrative, high local value added deals may be clinched (Oakey, 1984). Being small can prove a blessing in this field because external clients may wish to steer away from engaging consultants based in big states who may have political ambitions over-riding international trade relations (CIBS, 1998). Furthermore, potential exists to utilise the new and promising technologies for the adoption of more innovative, small scale manufacturing processes and for the tapping of larger export markets, including the 'privileged export' type mentioned above (Baldacchino and Milne, forthcoming)

Generally, human capital investment at home and abroad through a global labour market orientation is enormously important to most remote microstates because they allow their citizens to usurp insularity and participate in the global economy. This keeps alive a pragmatic juxtaposition of their economy, society and culture with the outside world. There is indeed a schizoid interplay of openness and closure at work here, since the world's smallest states exhibit high levels of both isolation as well as of 'exit' options and extra-territorial mobility (Baldacchino 1997: 89; Villamil, 1977).

\section{Occupational flexibility}

Fourthly and lastly, while the above is going on, small islanders maintain a dual orientation to the economy. One market based, where there is promise of profit but also risk; and one domestically oriented providing for the needs of the local populace: petty commodity production, food processing, beverages, peasant subsistence agriculture, home-working ... The latter may not be sufficient to provide a decent means of livelihood by themselves; but they constitute a handsome income supplement which may not figure in the market/money circuit. Such 'occupational multiplicity' (Comitas, 1963: 41) is a natural survival strategy and a characteristic of areas where employment opportunities are scarce, precarious and seasonal (Brookfield, 1975: 56-7,71; Croulet \& Sio, 1986: 36; Frucht, 1967: 291; Trouillot, 1988: 32). The involvement in diverse activities enables an intensive use of scarce management skills and provides a measure of security, or fallback, in the event of failure (Fairbairn, 1988b: 270). It is also common to find small islanders engaged in such production activities while they obtain their main source of income from public sector employment, ever so sprawling in small island states. 


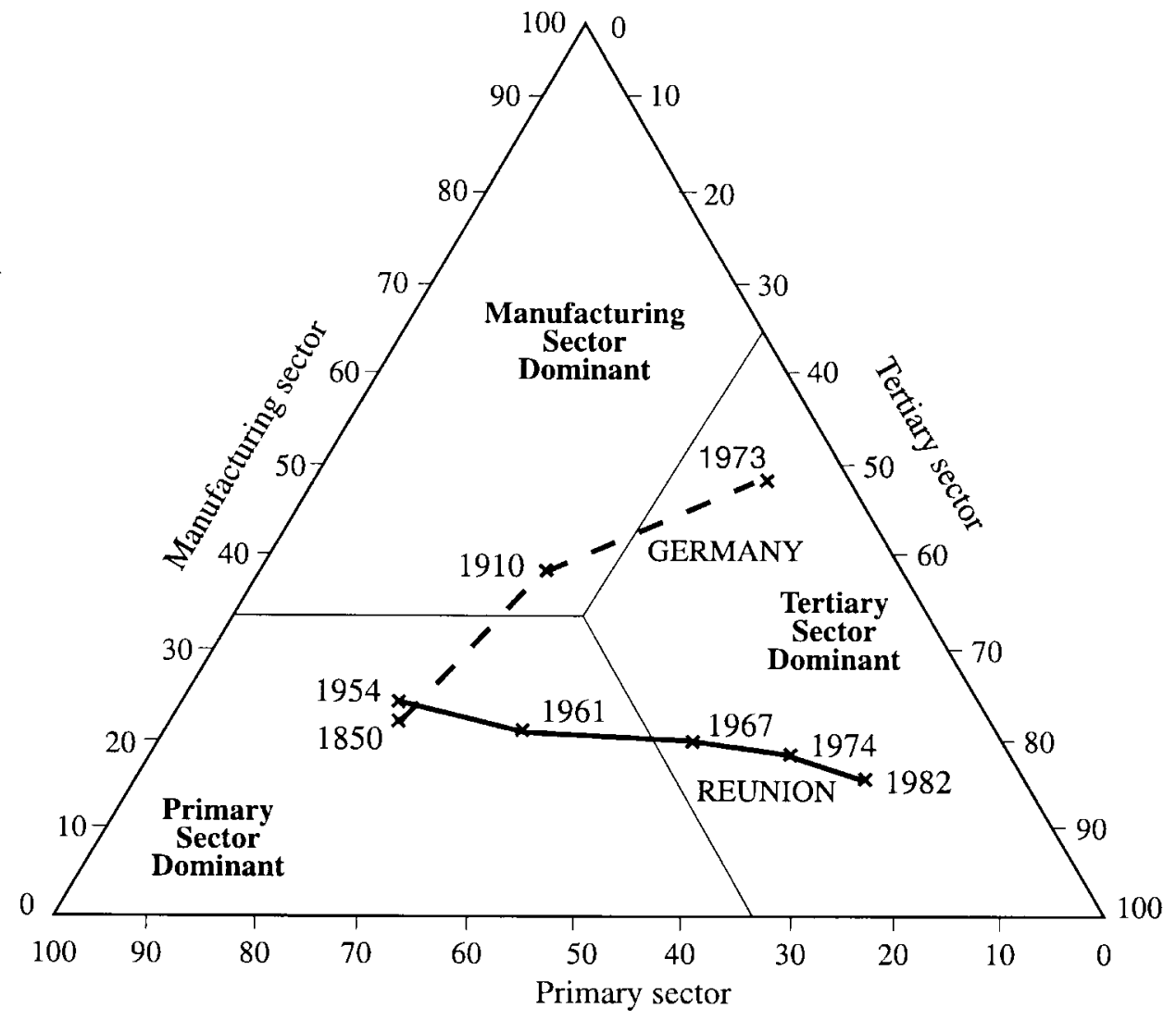

Figure 1. Tri-sectoral evolution of gainfully occupied population in a small island (Réunion) Source: Squarzoni (1987: 275) and in a developed economy (Germany)

The sum effects of such policies is a strategy which considers services as the single, comparative and competitive advantage of microstates, within a context of the pursuit of 'opportunist pragmatism' (Moen, 1982: 345) which considers industrialisation as a welcome but suspicious appendix to the micro-economy. As exemplified in Figure 1 micro-economies appear better suited to, first, leapfrog directly from an agrarian/subsistence to a service economy and only then to industrialise as a consequence of tertiarisation. ${ }^{2}$ There is a clear departure from the 'closed economy' and 'development in one country' models which are fallacious in micro-territorial contexts (Baldacchino \& Greenwood, 1998). The alternatives in hand militate against mainstream conceptions of viability and self-reliance; nevertheless, they have, so far, worked - at least in terms of guaranteeing living standards typically higher than those of other developing countries (Briguglio, 1995; Kakazu, 1988). There is no reason to expect the world's small developing states to fail in a more vigorous, pragmatic pursuit of such development policies. 


\section{CONCLUSION}

Today, globalisation appears to have replaced development as the onerous straight-jacket, obliging all and sundry to conform. Many are waxing fatalistic at the prospects of some successful kind of contest of the powerful global players by local forces and cultures. Yet, even here, there are traces of hard evidence of how even small islanders can disturb the corporate project and infect it with nuances and idiosyncracies, questioning its one-way, monist precepts (Baldacchino, 1997). There are important lessons to be learnt when one looks at small insular sites on their own terms. The relationship between manufacturing and services in such small territories is one policy arena soliciting an unorthodox, open minded approach. After all, the maintenance of a respectable quality of life is the essence of survival (Cohen, 1987: 212). Small islanders just do it differently. If they constitute a 'paradox' (e.g. Abbott, 1975) or a 'special case' (e.g. Kaplinsky, 1983) of development, well frankly that is someone else's problem.

\section{ACKNOWLEDGEMENTS}

An earlier version of this article was presented at the VIIIth Pacific Science Inter-Congress held at the University of the South Pacific, Fiji in July 1997. My gratitude to the Association of Commonwealth Universities, the University of the South Pacific and the University of Malta for supporting my participation in this event. My thanks to Geoff Bertram, Anand Chand, Rajesh Chandra, Ross Garnaut, Wadan Narsey, Nii-K Plange, Bernard Poirine, K. L. Sharma as well as Philip Morrison and the anonymous referees of Asia Pacific Viewpoint for their insightful comments on the earlier draft. Responsibility for the contents remains solely my own.

\section{NOTES}

1 Smallness is an arbitrary term and there is no objective cut-off point. The most common benchmark is a resident population of not more than 1 million. Restricting ourselves to sovereign (mainly island) states would leave us with some two dozen candidates, of which 10 are in the South Pacific, 8 in the Caribbean and 3 in the Indian Ocean. (See also Table 1.)

2 Using a 3-sector model developed by Squarzoni (1987) to analyse Réunion, the developmental route moves from agriculture directly to services and only then to industry in the case of small territories; rather than the classical, evolutionary model of agriculture to industry and finally to services. (See Figure 1.)

\section{REFERENCES}

Abbott, G.C. (1975) Small states: the paradox of their existence. In P. Selwyn (ed) Development policy in small countries London: Croom Helm, pp. 105-114.

Armstrong, H. and Read, R. (1998) Trade and growth in small states: the impact of trade liberalisation, World Economy 21(4): 563-585.

Bacchus, M. K. (1989) Educational needs of small nation states with special reference to education at the post-secondary level Canadian and International Education 18(1): 5-17. 
Baldacchino, G. (1993) Bursting the bubble: The pseudo-development strategies of microstates Development and Change 24(1): 29-51.

Baldacchino, G. (1997) Global tourism and informal labour relations: The small scale syndrome at work London: Mansell.

Baldacchino, G. and Greenwood, R. (eds) (1998) Competing strategies of socio-economic development for small islands Charlottetown, Canada: University of Prince Edward Island, Institute of Island Studies.

Baldacchino, G. and Milne, D. (eds) (forthcoming) A political economy for small islands, Basingstoke: Macmillan.

Barrow, C. and Greene, J.E. (1979) Small business in Barbados: A case of survival Barbados: University of the West Indies, Institute of Social and Economic Development.

Barry, T., Wood, B. and Preusch, D. (1984) The other side of paradise: Foreign control in the Caribbean New York: Grove Press.

Bertram, I.G. (1988) The political economy of decolonisation and nationhood in small Pacific societies. In A. Hooper, S.G. Britton, R. Crocombe, J. Huntsman and C. Macpherson (eds.) Class and culture in the South Pacific Suva, University of the South Pacific: Institute of Pacific Studies, pp.16-29.

Bertram, I.G. (1993) Sustainability, aid and material welfare in small South Pacific island economies: 1900-1990 World Development 21(2): 247-258.

Bertram, I. G. and Watters, R. F. (1985) The MIRAB economy in south pacific microstates Pacific Viewpoint 26(3): 497-519.

Briguglio, L. (1995) A vulnerability index for small island economies World Development 23(9): 1615-1632.

Brookfield, H.C. (1975) Multum in parvo: Questions about diversity and diversification in small developing countries. In P. Selwyn (ed) Development policy in small countries London: Croom Helm, pp. 54-76.

Brookfield, H.C. (1987) Export or perish: Commercial agriculture in Fiji. In M. J. Taylor (ed) Fiji: future imperfect London: Allen and Unwin, pp. 46-57.

Chattopadhyay, A. (1987) Labour and development. In R.E. Boyd, R. Cohen and P.C.W. Gutkind (eds) International labour and the third world: the making of a new working class Aldershot: Gower, pp. 48-69.

Centre for International Business Studies (CIBS) (1998) Small places, big ideas: exporting knowledge based services from the atlantic periphery, St. John's, Newfoundland, Canada: Memorial University of Newfoundland, Centre for International Business Studies.

Cohen, E. (1972) Towards a sociology of international tourism Social Research 39(2): 164-182.

Cohen, R. (1987) An academic perspective. In C. Clarke and T. Payne (eds) Politics, development and security in small states London: Allen and Unwin, pp. 203-213.

Comitas, L. (1963) Occupational multiplicity in rural Jamaica. Proceedings of the annual spring meeting of the American Ethnological Society, Seattle.

Commonwealth Secretariat (1996) Small states: economic review and basic statistics London: Commonwealth Secretariat.

Commonwealth Secretariat (1997) A future for small states: overcoming vulnerability London: Commonwealth Secretariat.

Connell, J. (1991) Island microstates: The mirage of development Contemporary Pacific 3(2): 251-287.

Connell, J. (1992) The back door of bureaucracy: employment and development in Yap State and Woleai Atoll, Federated States of Micronesia. In R. Baker (ed) Public administration in small and island states West Hartford CT: Kumarian Press, pp.174-192.

Crocombe, R. (1987) Productive potentials of the Pacific islands Journal of the Pacific Society 7: $21-40$.

Croulet, C.R. and Sio, L. (1986) Indigenous entrepreneurship in Western Samoa Honolulu: East West Centre, Pacific Islands Development Programme.

Crusol, J. (1980) Economiés insulaires de la Caraïbe, Paris: Editions Caribïennes. 
Demas, W.G. (1965) The economics of development in small countries with special reference to the Caribbean, Montreal, Canada: McGill University Press.

Dommen, E.C. and Hein, P.L. (eds) (1985) States, microstates and islands, London: Croom Helm.

Faber, M. (1992) Microstates, increasing integration and awkward imperatives of adjustment: The case of the Republic of the Maldives. In H.M. Hintjens and M.D.D. Newitt, (eds) The political economy of small tropical islands: The importance of being small Exeter: University of Exeter Press, pp. 123-149.

Fairbairn, T.I.J. (1988a) Indigenous entrepreneurship and business development in the Cook Islands. in Island entrepreneurs: problems and performance in the Pacific. Hawaii: University of Hawaii Press, pp.55-76.

Fairbairn, T.I.J. (1988b) Assessment and conclusions. in Island entrepreneurs: problems and performance in the Pacific. Hawaii: University of Hawaii Press, pp.269-276.

Frucht, R. (1967) A Caribbean social type: neither peasant nor proletarian Social and Economic Studies 16(2): 295-200.

Hettne, B. (1990) Development theory and the three worlds. Harlow, Essex: Longman.

Hoefte, R. and Oostindie, G. (1990) The Netherlands and the Dutch Caribbean: dilemmas of decolonisation. In P. Sutton (ed) Europe and the Caribbean London: Macmillan, pp.71-98.

Hoetjes, B.J.S. (1992) The Dutch connection in the Caribbean: six islands living apart together. In R. Baker (ed) Public administration in small and island states West Hartford CT: Kumarian Press, pp. 131-143.

Hyden, G. (1983) No shortcuts to progress: African development management in perspective London: Heinemann.

Jalan, B. (ed) (1982) Problems and policies in small economies, London: Croom Helm.

Kakazu, H. (1988) Resources and development of small island economies: A rent seeking approach. Paper presented at conference on industrialisation and economic development of South Pacific island states, Suva, Fiji, University of the South Pacific and the Friedrich Ebert Foundation.

Kaplinsky, R. (1983) Prospering at the periphery: A special case: The Seychelles. In R. Cohen (ed) African islands and enclaves London: Sage, pp.195-215.

Katzenstein, P. (1985) Small states in world markets: industrial policy in Europe London: Cornell University Press.

Khan, J. (1976) Development administration: Field research in Barbados Bridgetown, Barbados: Yoruba Press.

Legarda, B. (1984) Small island economies Finance and Development 21(2): 42-3.

Lowenthal, D. (1987) Social features. In C. Clarke and T. Payne (eds) Politics, security and development in small states London: Allen and Unwin, pp.26-49.

McKee, D.L. and Tisdell, C.A. (1990) Development issues in small island states New York: Praeger.

Moen, A. (1982) Curaçao 1969: crisis and change. In S. Craig (ed) Contemporary Caribbean: A sociological reader Vol. 2, Trinidad: The College Press, pp. 337-364.

Oakey, M. (1984) High technology, new firms London: Frances Pinter.

Payne, T. (1991) Britain and the Caribbean. In P. Sutton (ed) Europe and the Caribbean London: Macmillan, pp.13-36.

Perlmutter, H.V. (1969) The tortuous evolution of the multinational corporation Columbia Journal of World Business Jan/Feb., p.12.

Poirine, B. (1995) Les petites économies insulaires: Théories et stratégies de developpement, Paris: l'Harmattan Press.

Preston, P.W. (1982) Theories of development London: Routledge and Kegan Paul.

Ramsaran, R. (1989) The Commonwealth Caribbean in the world economy London: Macmillan.

Robertson, R. (1992) Globalisation: social theory and global culture London: Sage.

Rostow, W.W. (1956) The take-off into self-sustaining growth Economic Journal 66 (1): 25-48.

Seers, D. (1982) The new role of development planning. In B. Jalan (ed) Problems and policies in small economies London: Croom Helm, pp. 69-84. 
Selwyn, P. (1975) Room for manoeuvre? In P. Selwyn (ed) Development policy in small countries London: Croom Helm, pp.8-24.

Squarzoni, R. (1987) L'Emploi à la Réunion. In J.P. Doumenge, M.F. Perrin, J.P. Benoist, Singaravelou and C. Huetz de Lemps (eds) Îles Tropicales: Insularité, Insularisme France: CRET, pp. 273-294.

Streeten, P. (1993) The special problems of small countries World Development 21(2): 197202.

Sutton, P. (1987) Political aspects. In C. Clarke and T. Payne (eds) Politics, security and development in small states London: Allen and Unwin, pp.3-25.

Taylor, M.J. (1987) Issues in Fiji's development: economic rationality or aid with dignity? In M.J. Taylor (ed) Fiji: Future imperfect London: Allen and Unwin, pp.1-13.

Trouillot, M.R. (1988) Peasants and capital: Dominica in the world economy London: Johns Hopkins University Pess.

Waugh, G. (1987) The collection of rent in the south pacific tuna fishery. Islands/Australia Working Paper No.3/87 Canberra: Australia National University, Research School for Pacific Studies.

Watters, R.F. (1988) MIRAB societies and bureaucratic elites. In A. Hooper, S.G. Britton, R. Crocombe, J. Huntsman and C. Macpherson (eds) Class and culture in the South Pacific Suva, University of the South Pacific: Institute of Pacific Studies, pp.32-55.

Wilkinson, P. (1989) Strategies for tourism in island microstates Annals of Tourism Research 16(1): 153-177.

Will, W.M. (1981) Mass political party institutionalisation in Barbados, Journal of Commonwealth and Comparative Politics 19(1): 134-156.

Winchester, S. (1985) Outposts: Journeys to the surviving relics of the British Empire Sevenoaks: Sceptre Books 